\title{
Liquid-liquid phase separation in secondary organic aerosol particles produced from $\alpha$-pinene ozonolysis and $\alpha$-pinene photooxidation with/without ammonia
}

\author{
Suhan Ham ${ }^{1}$, Zaeem Bin Babar ${ }^{2}$, Jae Bong Lee ${ }^{3}$, Ho-Jin Lim² ${ }^{2}$, and Mijung Song ${ }^{1}$ \\ ${ }^{1}$ Department of Earth and Environmental Sciences, Chonbuk National University, 567 Baekje-daero, \\ Deokjingu, Jeonju-si 54896, Jeollabuk-do, South Korea \\ ${ }^{2}$ Department of Environmental Engineering, Kyungpook National University, 80 Daehakro, Bukgu, \\ Daegu 41566, South Korea \\ ${ }^{3}$ Reactor System Safety Research Division, Korea Atomic Energy Research Institute, 989-111 Daedeok-daero, \\ Yuseonggu, Daejeon 34057, South Korea
}

Correspondence: Mijung Song (mijung.song @jbnu.ac.kr)

Received: 8 January 2019 - Discussion started: 24 January 2019

Revised: 9 June 2019 - Accepted: 25 June 2019 - Published: 22 July 2019

\begin{abstract}
Recently, liquid-liquid phase separation (LLPS) of secondary organic aerosol (SOA) particles free of inorganic salts has been intensively studied due to the importance of cloud condensation nuclei $(\mathrm{CCN})$ properties. In this study, we investigated LLPS in four different types of SOA particles generated from $\alpha$-pinene ozonolysis and $\alpha$-pinene photooxidation in the absence and presence of ammonia $\left(\mathrm{NH}_{3}\right)$. LLPS was observed in SOA particles produced from $\alpha$ pinene ozonolysis at $\sim 95.8 \%$ relative humidity (RH) and $\alpha$-pinene ozonolysis with $\mathrm{NH}_{3}$ at $\sim 95.4 \% \mathrm{RH}$. However, LLPS was not observed in SOA particles produced from $\alpha$-pinene photooxidation and $\alpha$-pinene photooxidation with $\mathrm{NH}_{3}$. Based on datasets of the average oxygen to carbon elemental ratio $(\mathrm{O}: \mathrm{C})$ for different types of SOA particles from this study and from previous studies, there appears to be a relationship between the occurrence of LLPS and the O : C of the SOA particles. When LLPS was observed, the two liquid phases were present up to $\sim 100 \% \mathrm{RH}$. This result can help more accurately predict the $\mathrm{CCN}$ properties of organic aerosol particles.
\end{abstract}

\section{Introduction}

Secondary organic aerosol (SOA) particles in the atmosphere can be formed by the oxidation of volatile organic compounds (VOCs) emitted from biogenic and anthropogenic sources (Hallquist et al., 2009). These SOA particles may comprise a large fraction of ultrafine aerosol particles depending on the location (Zhang et al., 2007; Jimenez et al., 2009). They can affect the energy balance of the Earth by scattering and absorbing solar radiation and also by acting as nuclei for cloud formation (Kanakidou et al., 2005; Hallquist et al., 2009; IPCC, 2013; Knopf et al., 2018). In addition, these particles can affect air quality and human health (Kanakidou et al., 2005; Jang et al., 2006; Forster et al., 2007; Baltensperger et al., 2008; Murray et al., 2010; Wang et al., 2012; Pöschl and Shiraiwa, 2015; Shiraiwa et al., 2017).

Many previous studies have shown that SOA particles can be formed more efficiently in the presence of gaseous species such as ammonia $\left(\mathrm{NH}_{3}\right)$ (Zhang et al., 2004; Na et al., 2006, 2007; Laskin et al., 2014; T. Y. Liu et al., 2015; Y. Liu et al., 2015; Babar et al., 2017). $\mathrm{NH}_{3}$ is one of the abundant and reactive gaseous species in the atmosphere (Reis et al., 2009; Heald et al., 2012; Reche et al., 2015; Zheng et al., 2015; Sharma et al., 2016; Warner et al., 2016). The chemical composition of SOA particles can be influenced by reaction with $\mathrm{NH}_{3}$ (Laskin et al., 2015; Y. Liu et al., 2015b), but the chemical composition from the reaction is still poorly understood. 
Aerosol particles containing SOAs can undergo phase transitions in the atmosphere as relative humidity (RH) changes. Thus far, many researchers have focused on phase transitions, especially liquid-liquid phase separation (LLPS) in particles containing SOAs and inorganic salts during changes in RH (Pankow, 2003; Marcolli and Krieger, 2006; Ciobanu et al., 2009; Bertram et al., 2011; Krieger et al., 2012; Song et al., 2012a, b; Zuend and Seinfeld., 2012; Ault et al., 2013; Veghte et al., 2013; O'Brien et al., 2015). They established that LLPS always occurs in SOA particles mixed with inorganic salts when the oxygen to carbon elemental ratio $(\mathrm{O}: \mathrm{C})$ of the organic materials is lower than 0.56 , whereas LLPS never occurs when the $\mathrm{O}: \mathrm{C}$ of the organic materials is higher than 0.80 . LLPS commonly occurs in the intermediate $\mathrm{O}: \mathrm{C}$ range (Bertram et al., 2011; Krieger et al., 2012; Song et al., 2012a, 2013; You et al., 2013, 2014). LLPS in a mixture of SOA particles and inorganic salts is known to affect the optical properties (Fard et al., 2018), gas-particle partitioning (Zuend et al., 2010; Zuend and Seinfeld, 2012; Shiraiwa et al., 2013), reactivity (Kuwata and Martin, 2012), hygroscopic properties (Hodas et al., 2016) and cloud condensation nuclei $(\mathrm{CCN})$ properties of these particles (Hodas et al., 2016; Ovadnevaite et al., 2017; Rastak et al., 2017; Altaf et al., 2018).

More recently, researchers have focused on LLPS in SOA particles in the absence of inorganic salts (Petters et al., 2006; Renbaum-Wolff et al., 2016; Rastak et al., 2017; Song et al., 2017,2018 ) as it is important to explore the CCN properties of the particles (Petters et al., 2006; Hodas et al., 2016; Renbaum-Wolff et al., 2016; Ovadnevaite et al., 2017; Rastak et al., 2017; Liu et al., 2018). Renbaum-Wolff et al. (2016) and Song et al. (2017) observed LLPS at a high RH of $\sim 95 \%-100 \%$ in SOA particles produced from the ozonolysis of $\alpha$-pinene, $\beta$-caryophyllene and limonene. However, Rastak et al. (2017) and Song et al. (2017) did not observe LLPS in SOA particles produced from the photooxidation of isoprene and toluene. The occurrence of LLPS in SOA particles free of inorganic salts was related to the average $\mathrm{O}: \mathrm{C}$ of the organic materials. When the average $\mathrm{O}: \mathrm{C}$ of the SOA particle was less than $\sim 0.44$, LLPS was observed in the SOA particles free of inorganic salts (Renbaum-Wolff et al., 2016; Rastak et al., 2017; Song et al., 2017). Song et al. (2018) studied organic particles consisting of one and two commercially available organic species free of inorganic salts and found that the average $\mathrm{O}: \mathrm{C}$ of the organic material can be an important parameter to predict LLPS. LLPS was observed in particles containing one organic species at an $\mathrm{O}: \mathrm{C}$ of $\leq 0.44$ and in particles containing two organic species at an $\mathrm{O}: \mathrm{C}$ of $\leq 0.58$. As few systems have been studied thus far, more studies are needed to confirm the effect of $\mathrm{O}: \mathrm{C}$ on the LLPS in organic particles.

Herein, we investigated LLPS in SOA particles produced from the ozonolysis and photooxidation of $\alpha$-pinene. Moreover, we studied the effects of $\mathrm{NH}_{3}$ on SOA particles pro- duced from the ozonolysis and photooxidation of $\alpha$-pinene on the occurrence of LLPS.

\section{Experimental}

\subsection{Production of SOA particles}

Four different types of SOA particles were generated in the flow tube reactor of Kyungpook National University (KNU), South Korea: those produced via $\alpha$-pinene ozonolysis and $\alpha$ pinene photooxidation in the absence of $\mathrm{NH}_{3}$ (Table 1), and those produced via $\alpha$-pinene ozonolysis and $\alpha$-pinene photooxidation in the presence of $\mathrm{NH}_{3}$ (Table 2). The method of SOA particle generation was previously described by Babar et al. (2017). The flow tube reactor was run at a flow rate of $4.0 \mathrm{~L} \mathrm{~min}^{-1}$, with a residence time of $3.63 \mathrm{~min}$ at $\sim 10 \% \mathrm{RH}$.

$\alpha$-pinene at a concentration of $1000 \mathrm{ppb}$ was injected into the flow tube reactor to produce SOA particles via ozonolysis without $\mathrm{NH}_{3} \cdot \mathrm{O}_{3}$ was produced by passing high purity $\mathrm{O}_{2}$ through a UV lamp $(\lambda=185 \mathrm{~nm})$ and was injected into the flow tube reactor at a concentration of $10000 \mathrm{ppb}$. Table 1 presents the experimental conditions for the ozonolysis.

To produce SOA particles via photooxidation in the absence of $\mathrm{NH}_{3}, 1000 \mathrm{ppb}$ of $\alpha$-pinene was injected in the flow tube reactor (Table 1 ). The $\mathrm{OH}$ radical was produced by photodissociation of $\mathrm{O}_{3}$ by irradiating $\mathrm{O}_{3}$ with $\mathrm{UV}(\lambda=254 \mathrm{~nm})$ in the presence of water vapor. The following photochemical reactions take place:

$\mathrm{O}_{3}+h v \rightarrow \mathrm{O}_{2}+\mathrm{O}$

$\mathrm{O}+\mathrm{H}_{2} \mathrm{O} \rightarrow 2 \mathrm{OH}$

In the flow tube reactor, $\mathrm{OH}$ concentrations were determined from the photochemical decay of toluene, as toluene is well known for its $\mathrm{OH}$ reaction rate. The $\mathrm{OH}$ reaction rate constant $\left(k_{\mathrm{OH}}\right)$ of toluene is $5.48 \times 10^{-12}$ molecules $\mathrm{cm}^{-3} \mathrm{~s}^{-1}$ with an insignificant reaction rate with $\mathrm{O}_{3}$ (Atkinson and Aschmann, 1989). The $\mathrm{OH}$ concentrations were calculated by varying $\mathrm{O}_{3}$ and $\mathrm{RH}$ from 2000 to $8000 \mathrm{ppb}$ and $10 \%$ to $60 \%$, respectively. The $\mathrm{OH}$ concentrations were calculated by the first-order decay of toluene by reaction with $\mathrm{OH}$ radicals (Babar et al., 2017). Assuming an atmospheric $\mathrm{OH}$ concentration of $1.5 \times 10^{6}$ molecules $\mathrm{cm}^{-3}$, $\mathrm{OH}$ exposures were $8.2 \times 10^{10}$ and $2.3 \times 10^{11}$ molecules $\mathrm{cm}^{-3} \mathrm{~s}$, corresponding to an atmospheric aging time of 0.5 and $2.5 \mathrm{~d}$, respectively, and the concentrations of $\mathrm{O}_{3}$ in the reactor were 2000 and $6000 \mathrm{ppb}$ at $10 \% \mathrm{RH}$, respectively.

The same method was used for the SOA particle generation via ozonolysis and photooxidation in the presence of $\mathrm{NH}_{3}$, the exception being that $\mathrm{NH}_{3}$ was injected into the flow tube reactor during particle generation. The concentration of $\mathrm{NH}_{3}$ injected was $2000 \mathrm{ppb}$ for the ozonolysis and photooxidation (Table 2).

The $4 \mathrm{~L} \mathrm{~min}^{-1}$ mainstream flow of SOA particles at the outlet of the flow tube reactor was diluted by a humidified air 
Table 1. Experimental conditions for production and collection of SOA particles from $\alpha$-pinene ozone (termed " $\alpha$-pinene $\mathrm{O}_{3}$ ”) and photooxidation (termed " $\alpha$-pinene OH”). The separation relative humidity (SRH) upon moistening and the merging relative humidity (MRH) upon drying are listed. The SRH is the RH at which liquid-liquid phase separation occurred. The MRH is the RH at which two phases merged into one phase. The uncertainties indicate the $2 \sigma$ from several humidity cycles for one sample and from the uncertainty of the calibration. SRH and MRH values of zero indicate that phase separation was not observed. "conc." refers to concentration.

\begin{tabular}{lrrrrrrrr}
\hline $\begin{array}{l}\text { SOA } \\
\text { sample }\end{array}$ & $\begin{array}{r}\alpha \text {-pinene } \\
\text { conc. } \\
(\mathrm{ppb})\end{array}$ & $\begin{array}{r}\mathrm{OH} \\
\text { exposure } \\
(\mathrm{day})\end{array}$ & $\begin{array}{r}\mathrm{O}_{3} \\
\mathrm{conc} . \\
(\mathrm{ppb})\end{array}$ & $\begin{array}{r}\mathrm{NH}_{3} \\
\text { conc. } \\
(\mathrm{ppb})\end{array}$ & $\begin{array}{r}{ }^{*} \text { Mass } \\
\text { conc. } \\
\left(\mu \mathrm{g} \mathrm{m}^{-3}\right)\end{array}$ & $\begin{array}{r}* \text { Geometric mean } \\
\text { diameter } \\
(\mathrm{nm})\end{array}$ & $\begin{array}{r}\text { SRH } \\
(\%)\end{array}$ & $\begin{array}{r}\mathrm{MRH} \\
(\%)\end{array}$ \\
\hline$\alpha$-pinene $\mathrm{O}_{3}$ no. 1 & 1000 & - & 10000 & 0 & 481 & 63 & $96.0 \pm 2.3$ & $94.3 \pm 3.1$ \\
$\alpha$-pinene $\mathrm{O}_{3}$ no. 2 & 1000 & - & 10000 & 0 & 493 & 63 & $95.4 \pm 2.0$ & $91.6 \pm 4.4$ \\
$\alpha$-pinene OH no. 1 & 1000 & 0.5 & 2000 & 0 & 688 & 67 & 0 & 0 \\
$\alpha$-pinene OH no. 2 & 1000 & 2.5 & 6000 & 0 & 479 & 67 & 0 & 0 \\
$\alpha$-pinene OH no. 3 & 1000 & 0.5 & 2000 & 0 & 633 & 67 & 0 & 0 \\
$\alpha$-pinene OH no. 4 & 1000 & 2.5 & 6000 & 0 & 618 & 66 & 0 \\
\hline
\end{tabular}

* After dilution of $4 \mathrm{~L} \mathrm{~min}^{-1}$ mainstream with $7 \mathrm{~L} \mathrm{~min}^{-1}$ of humidified air at $60 \% \mathrm{RH}$.

Table 2. Experimental conditions for the production and collection of SOA particles from $\alpha$-pinene ozone with $\mathrm{NH}_{3}$ (termed " $\alpha$-pinene $\mathrm{O}_{3} / \mathrm{NH}_{3}$ ") and photooxidation with $\mathrm{NH}_{3}$ (termed " $\alpha$-pinene $\mathrm{OH} / \mathrm{NH}_{3}$ "). The separation relative humidity (SRH) upon moistening and the merging relative humidity (MRH) upon drying are listed. The SRH is the RH at which liquid-liquid phase separation occurred. The MRH is the RH at which two phases merged into one phase. The uncertainties indicate the $2 \sigma$ from several humidity cycles for one sample and from the uncertainty of the calibration. SRH and MRH values of zero indicate that LLPS was not observed.

\begin{tabular}{lrrrrrrrr}
\hline $\begin{array}{l}\text { SOA } \\
\text { sample }\end{array}$ & $\begin{array}{r}\alpha \text {-pinene } \\
\text { conc. } \\
(\mathrm{ppb})\end{array}$ & $\begin{array}{r}\mathrm{OH} \\
\text { exposure } \\
(\text { day })\end{array}$ & $\begin{array}{r}\mathrm{O}_{3} \\
\text { conc. } \\
(\mathrm{ppb})\end{array}$ & $\begin{array}{r}\mathrm{NH}_{3} \\
\text { conc. } \\
(\mathrm{ppb})\end{array}$ & $\begin{array}{r}* \text { Mass } \\
\text { conc. } \\
\left(\mu \mathrm{g} \mathrm{m}^{-3}\right)\end{array}$ & $\begin{array}{r}* \text { Geometric mean } \\
\text { diameter } \\
(\mathrm{nm})\end{array}$ & $\begin{array}{r}\mathrm{SRH} \\
(\%)\end{array}$ & $\begin{array}{r}\mathrm{MRH} \\
(\%)\end{array}$ \\
\hline$\alpha$-pinene $\mathrm{O}_{3} / \mathrm{NH}_{3}$ no. 1 & 1000 & - & 10000 & 2000 & 564 & 68 & $95.4 \pm 3.0$ & $94.0 \pm 2.6$ \\
$\alpha$-pinene $\mathrm{O}_{3} / \mathrm{NH}_{3}$ no. 2 & 1000 & - & 10000 & 2000 & 579 & 68 & $95.4 \pm 3.4$ & $95.1 \pm 2.1$ \\
$\alpha$-pinene $\mathrm{OH} / \mathrm{NH}_{3}$ no. 1 & 1000 & 2.5 & 6000 & 2000 & 753 & 73 & 0 \\
$\alpha$-pinene $\mathrm{OH} / \mathrm{NH}_{3}$ no. 2 & 1000 & 0.5 & 2000 & 2000 & 886 & 74 & 0 & 0 \\
\hline
\end{tabular}

* After dilution of $4 \mathrm{~L} \mathrm{~min}-1$ mainstream with $7 \mathrm{~L} \mathrm{~min}^{-1}$ of humidified air at $60 \% \mathrm{RH}$.

stream (RH of $60 \%$ ) of $7 \mathrm{~L} \mathrm{~min}^{-1}$. A diffusion dryer loaded with silica gel was used upstream of the scanning mobility particle sizer (SMPS+C, Grimm, Germany) for the measurement of dry SOA mass concentrations. After dilution, the mass concentrations of the SOA particles were measured to range between $\sim 480$ and $\sim 880 \mu \mathrm{g} \mathrm{m}^{-3}$ using the SMPS for different experimental conditions as presented in Tables 1 and 2. The sample and sheath flow rates of the SMPS were 0.3 and $3.0 \mathrm{~L} \mathrm{~min}^{-1}$, respectively. The SOA particles consisting of up to $\sim 5 \mu \mathrm{m}$ were collected at the outlet of the reactor on a siliconized substrate (siliconized glass slides of $18 \mathrm{~mm}$, Hampton Research, USA). Figure S1 in the Supplement is an example image of collected SOA particles derived from $\alpha$-pinene ozonolysis ( $\alpha$-pinene $\mathrm{O}_{3}$ no. 1 in Table 1 ) on a hydrophobic substrate at the outlet of the flow tube reactor.

For each experiment, the siliconized glass slide was initially cleaned three times with water and methanol. It was then dried by purging $\mathrm{N}_{2}$ gas. Finally, it was fixed in the Stage D collector plate of a Sioutas cascade impactor (SKC cat no. 225-370, USA), operated at $9 \mathrm{~L} \mathrm{~min}^{-1}$.

\subsection{Observation of liquid-liquid phase separation in SOA particles}

The observation of LLPS in a particle requires particle diameters of $20-80 \mu \mathrm{m}$. In order to obtain the appropriate particle sizes for the LLPS experiments, SOA particles sized up to $5 \mu \mathrm{m}$ collected on the siliconized substrate from the flow tube reactor were placed into a RH-controlled flow-cell coupled to an optical microscope (Olympus BX43, 40× objective) (Parsons et al., 2004; Pant et al., 2006; Bertram et al., 2011; Song et al., 2012b, 2018) at $\sim 100 \% \mathrm{RH}$; the particles then grew and coagulated for $\sim 60 \mathrm{~min}$. This process resulted in a particle size of 20-80 $\mu \mathrm{m}$ (Renbaum-Wolff et al., 2016). Once the particle size was appropriate for the LLPS experiments, humidity cycles were performed.

During a humidity cycle, the RH was reduced from $\sim 100 \%$ to $\sim 5 \%-10 \%$ lower than the $\mathrm{RH}$ at which the two liquid phases merged into one phase, followed by an increase to $\sim 100 \% \mathrm{RH}$ at a rate of $0.1 \%-0.5 \% \mathrm{RH} \mathrm{min}{ }^{-1}$. If LLPS was not observed, the RH was reduced from $\sim 100 \%$ to $\sim 0 \%$, and then it was increased to $\sim 100 \%$ at a rate of 
$0.5 \%-1.0 \% \mathrm{RH} \mathrm{min}^{-1}$. We did not observe a dependence of LLPS on the humidity ramp rate. The optical images of the SOA particles during the experiment were recorded every $5 \mathrm{~s}$ using a complementary metal oxide semiconductor detector (DigiRetina 16, Tucsen, China). All of the experiments were performed at a temperature of $289 \pm 0.2 \mathrm{~K}$.

The RH was controlled by the ratio of $\mathrm{N}_{2} / \mathrm{H}_{2} \mathrm{O}$ gas at a total flow rate of $500 \mathrm{sccm}$. The RH inside the flow-cell was determined using a temperature and humidity sensor (Sensirion SHT71, Switzerland) which was calibrated by observing the deliquescence $\mathrm{RH}$ for the following pure inorganic salts at $293 \mathrm{~K}$ : potassium carbonate ( $44 \% \mathrm{RH})$, sodium chloride $(76 \% \mathrm{RH})$, ammonium sulfate $(80.5 \% \mathrm{RH})$ and potassium nitrate particle (93.5\% RH) (Winston and Bates, 1960). The uncertainty of the RH after calibration was $\pm 2.0 \%$.

\section{Results and discussion}

\subsection{SOA particles produced from $\alpha$-pinene ozonolysis and $\alpha$-pinene photooxidation}

SOA particles generated by $\alpha$-pinene ozonolysis with a mass concentration of $\sim 500-1000 \mu \mathrm{g} \mathrm{m}^{-3}$ underwent humidity cycles at $289 \pm 0.2 \mathrm{~K}$. Figure 1 shows examples of optical images of a SOA particle $\left(\alpha\right.$-pinene $\mathrm{O}_{3}$ no. 1 in Table 1) produced from $\alpha$-pinene ozonolysis with increasing $\mathrm{RH}$. Only one phase was observed from 0 to $\sim 96 \% \mathrm{RH}$ (Fig. 1). At 96.6\% RH, LLPS occurred via a spinodal decomposition mechanism, which distributes many small inclusions (schlieren) throughout a particle (Ciobanu et al., 2009; Song et al., 2012b). After phase separation, at $\sim 97.0 \%$ RH, small droplets grew and coagulated to form inner and outer phases in the particle. As the RH increased further, the SOA particle displayed a core-shell morphology consisting of inner and outer phases. The two liquid phases coexisted up to $\sim 100 \% \mathrm{RH}$, as shown in Fig. 1. When the RH decreased from $\sim 100 \%$, the inner phase became smaller and merged into one phase at $\sim 95.0 \% \mathrm{RH}$. We assume that the inner phase is a water-rich phase and the outer phase is an organicrich phase as the size of the inner phase depends on changes in RH (Renbaum-Wolff et al., 2016; Song et al., 2017, 2018).

Table 1 summarizes the separation relative humidity (SRH) upon moistening and the merging relative humidity (MRH) upon drying. In all cases, the SOA mass concentration was $\sim 500-1000 \mu \mathrm{g} \mathrm{m}^{-3}$. LLPS was observed at $95.8 \pm 2.3 \% \mathrm{RH}$ for all SOA particles derived from $\alpha$-pinene ozonolysis, and the two phases merged into one phase at $92.9 \pm 4.6 \%$ RH. The uncertainties of the SRH and the MRH indicate the $2 \sigma$ from several humidity cycles for one sample and from the uncertainty of the calibration.

Renbaum-Wolff et al. (2016) observed LLPS in SOA particles derived from $\alpha$-pinene ozonolysis at $\sim 95 \% \mathrm{RH}$, which is consistent with our result. They also showed that LLPS in the particles did not depend on the SOA particle mass con- centrations between 75 and $11000 \mu \mathrm{g} \mathrm{m}^{-3}$. As the SOA particle mass concentration does not affect LLPS, in this study, we only focused on SOA particle mass concentrations between $\sim 500$ and $1000 \mu^{-3} \mathrm{~m}^{-3}$ for different types of SOA particles.

We also performed humidity cycles for SOA particles with mass concentrations between $\sim 500$ and $1000 \mu \mathrm{g} \mathrm{m}^{-3}$ derived from $\alpha$-pinene photooxidation. Table 1 summarizes the results of the humidity cycles. None of the SOA particles from $\alpha$-pinene photooxidation underwent LLPS during the RH cycles. Figure 2 shows examples of optical images of a SOA particle ( $\alpha$-pinene $\mathrm{OH}$ no. 2 in Table 1$)$ for increasing RH. From $0 \%$ RH to $100 \%$ RH, there was no evidence of the occurrence of LLPS in the particles.

\subsection{SOA particles produced from $\alpha$-pinene ozonolysis with $\mathrm{NH}_{3}$ and $\alpha$-pinene photooxidation with $\mathrm{NH}_{3}$}

Ammonia $\left(\mathrm{NH}_{3}\right)$ is an abundant and reactive gaseous species in the atmosphere (Reis et al., 2009; Heald et al., 2012; Reche et al., 2015; Zheng et al., 2015; Sharma et al., 2016; Warner et al., 2016). Previous studies have shown that SOA particles can be formed more effectively in the presence of $\mathrm{NH}_{3}$ (Zhang et al., 2004; Na et al., 2006, 2007; T. Y. Liu et al., 2015; Y. Liu et al., 2015; Babar et al., 2017). To investigate the effect of $\mathrm{NH}_{3}$ on LLPS in SOA particles, we studied LLPS in SOA particles using $\alpha$-pinene ozonolysis and photooxidation in the presence of $\mathrm{NH}_{3}$. Table 2 presents the experimental conditions for the particle generation. We used the experimental conditions of SOA particle generation via ozonolysis and photooxidation (Table 1) in this case too, but we injected $2000 \mathrm{ppb}$ of $\mathrm{NH}_{3}$ into the flow tube reactor during particle generation (Table 2).

We performed humidity cycles for the SOA particles produced from $\alpha$-pinene ozonolysis in the presence of $\mathrm{NH}_{3}$ for mass concentrations between $\sim 500$ and $1000 \mu \mathrm{g} \mathrm{m}^{-3}$. Figure 3 shows examples of the optical images of SOA particles produced by $\alpha$-pinene ozonolysis in the presence of $\mathrm{NH}_{3}$ as a function of increasing $\mathrm{RH}\left(\alpha\right.$-pinene $\mathrm{O}_{3} / \mathrm{NH}_{3}$ no. 1 in Table 2). Upon moistening, only one phase was present (Fig. 3). As RH increased, the one phase of the SOA particle was separated into two phases at $95.3 \% \mathrm{RH}$; the underlying mechanism for this separation was spinodal decomposition. At $95.6 \% \mathrm{RH}$, small inclusions in the particle coagulated and grew; then, as RH increased further, a coreshell morphology, with a shell consisting of an organic-rich phase and the core consisting of a water-rich phase on a substrate, was observed. The two liquid phases coexisted up to $\sim 100 \% \mathrm{RH}$. When the RH decreased from $\sim 100 \% \mathrm{RH}$, the inner phase of the particle became smaller, and, eventually, the inner phase merged into one phase at $94.4 \% \mathrm{RH}$.

Table 2 summarizes the results of average SRH and MRH during the humidity cycles for the SOA particles produced by $\alpha$-pinene ozonolysis in the presence of $\mathrm{NH}_{3}$. LLPS occurred 


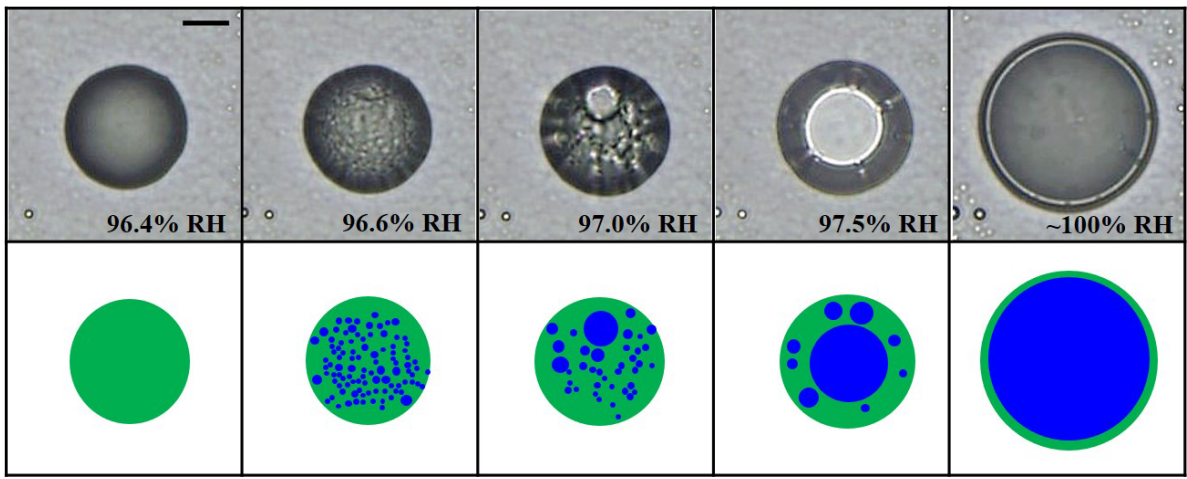

Figure 1. Optical images of a SOA particle produced from $\alpha$-pinene ozonolysis ( $\alpha$-pinene $\mathrm{O}_{3}$ no. 1 in Table 1$)$ with increasing RH. The purpose of the illustrations is to clarify the images. Green is the SOA-rich phase, and blue is the water-rich phase. The scale bar is $20 \mu \mathrm{m}$.

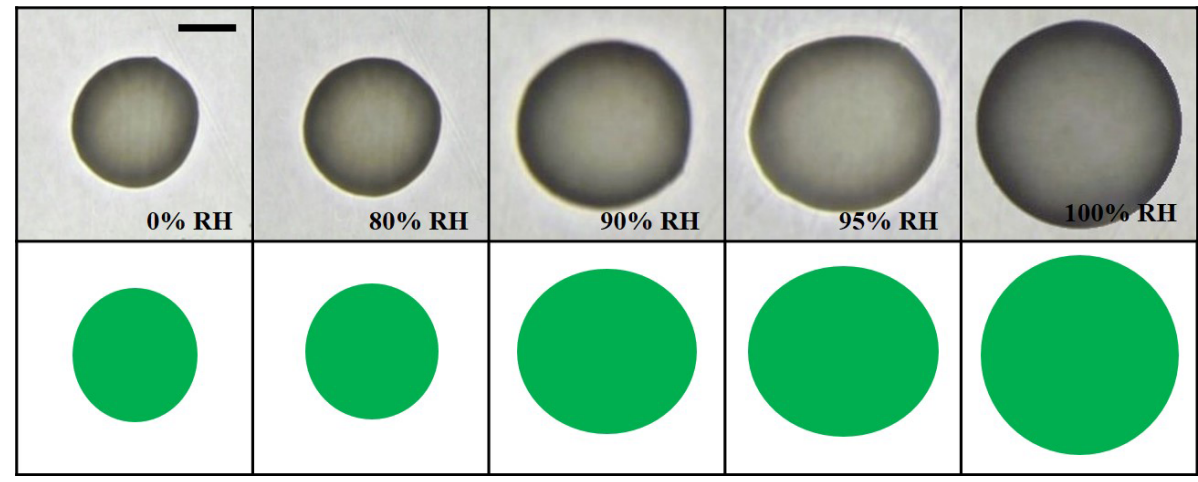

Figure 2. Optical images of a SOA particle produced from $\alpha$-pinene photooxidation ( $\alpha$-pinene OH no. 2 in Table 1$)$ with increasing RH. The purpose of the illustrations is to clarify the images. Green is the SOA-rich phase, and blue is the water-rich phase. The scale bar is $20 \mu \mathrm{m}$.

at $95.4 \pm 2.9 \% \mathrm{RH}$, and the two phases merged into one phase at $94.4 \pm 2.7 \% \mathrm{RH}$ for all of the particles (Table 2).

For SOA particles derived from $\alpha$-pinene photooxidation in the presence of $\mathrm{NH}_{3}$, no LLPS was observed during changes in RH. Table 2 lists the results of SRH and MRH for two different SOA particles derived from $\alpha$-pinene photooxidation in the presence of $\mathrm{NH}_{3}$. Figure 4 shows the examples of the optical images of SOA particles produced by $\alpha$-pinene with $\mathrm{NH}_{3}$ photooxidation for increasing $\mathrm{RH}(\alpha$ pinene $\mathrm{OH} / \mathrm{NH}_{3}$ no. 2 in Table 2). Only one phase was observed from $0 \% \mathrm{RH}$ to $100 \% \mathrm{RH}$.

\subsection{Phases of the four different types of SOA particles}

Figure 5 shows the RH at which two liquid phases were observed during RH scanning for the four different types of SOA particles. Circles represent the MRH upon drying, and triangles represent the SRH upon moistening. In the figure, the values of the SRH and MRH of SOA particles derived from $\alpha$-pinene ozonolysis by Renbaum-Wolff et al. (2016) are also included (in red). If the RH equals $0 \%$, no LLPS was observed.

Among the four different types of SOA particles, two types of particles underwent LLPS but the remaining particles did not (Fig. 5). For the SOA particles derived from $\alpha$-pinene ozonolysis, two liquid phases existed at $\sim 95.8 \pm 2.3 \% \mathrm{RH}$ up to $\sim 100 \pm 2.0 \% \mathrm{RH}$ with increasing RH. For values lower than $\sim 92.9 \pm 4.6 \% \mathrm{RH}$ with decreasing $\mathrm{RH}$, only one phase was observed. For the SOA particles derived from $\alpha$-pinene ozonolysis in the presence of $\mathrm{NH}_{3}$, the $\mathrm{RH}$ ranges for the two liquid phases were $\sim 95.4 \pm 2.9 \%$ and $\sim 100 \pm 2.0 \%$ with increasing RH. SRH values of both SOA particles were very similar within the uncertainties of the measurements. Furthermore, Fig. 5 showed that the values of SRH upon moistening and MRH upon drying for the two types of particles were close within the uncertainties of the measurements, suggesting that the kinetic barrier to LLPS in the particles is low. Compared with the SOA particles derived from $\alpha$-pinene ozonolysis and from $\alpha$-pinene ozonolysis with $\mathrm{NH}_{3}$, LLPS was not observed in SOA particles derived from $\alpha$-pinene photooxidation without/with $\mathrm{NH}_{3}$ (Fig. 5). In these cases, only one phase was present between $0 \% \mathrm{RH}$ and $100 \% \mathrm{RH}$.

\subsection{Relation between $\mathrm{O}: \mathrm{C}$ ratio and LLPS}

Recent studies have shown that the occurrence of LLPS in SOA particles free of inorganic salts is related to the average $\mathrm{O}: \mathrm{C}$ of the organic materials (Renbaum-Wolff et al., 2016; 


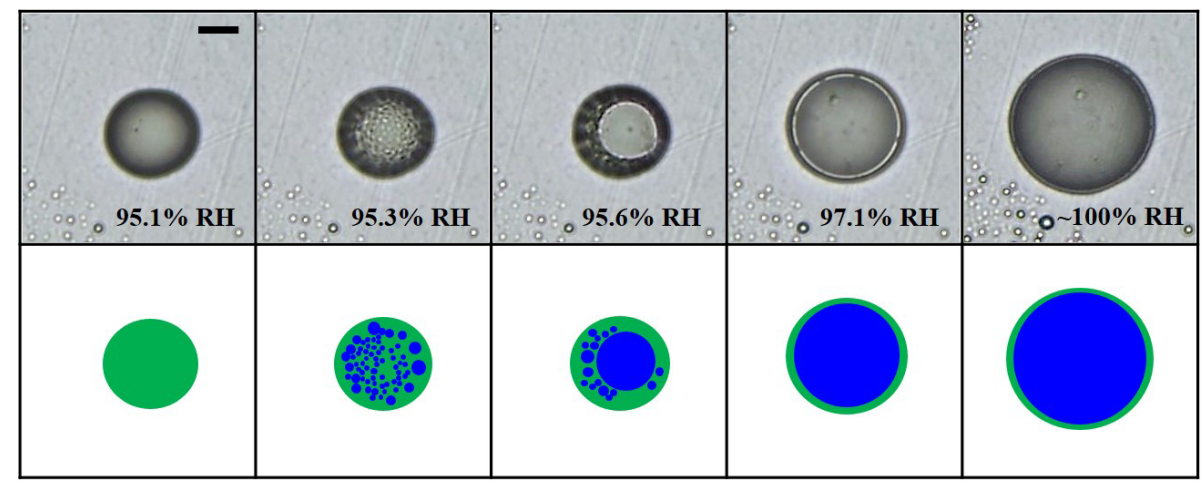

Figure 3. Optical images of a SOA particle produced from $\alpha$-pinene ozonolysis with $\mathrm{NH}_{3}\left(\alpha\right.$-pinene $\mathrm{O}_{3} / \mathrm{NH}_{3}$ no. 1 in Table 2) with increasing RH. The purpose of the illustrations is to clarify the images. Green is the SOA-rich phase, and blue is the water-rich phase. The scale bar is $20 \mu \mathrm{m}$.

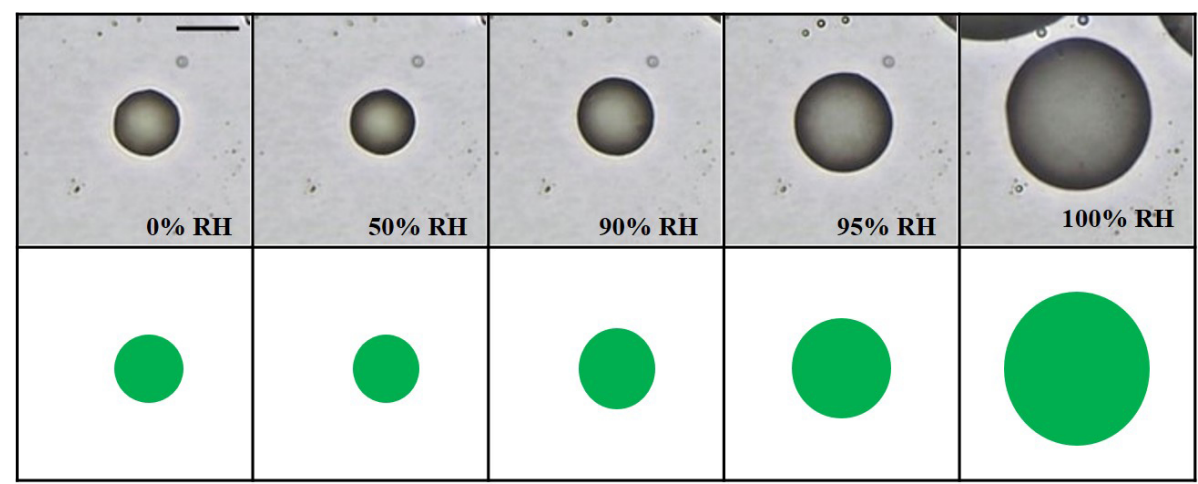

Figure 4. Optical images of a SOA particle produced from $\alpha$-pinene photooxidation with $\mathrm{NH}_{3}(\alpha$-pinene $\mathrm{OH} / \mathrm{NH} 3$ no. 2 in Table 1$)$ with increasing RH. The purpose of the illustrations is to clarify the images. Green is the SOA-rich phase, and blue is the water-rich phase. The scale bar is $20 \mu \mathrm{m}$.

Rastak et al., 2017; Song et al., 2017). These studies have shown that LLPS can occur in SOA particles derived from $\alpha$-pinene, limonene and $\beta$-caryophyllene for RH values between $\sim 95 \%$ and $\sim 100 \%$ when the average $\mathrm{O}: \mathrm{C}$ ranged between 0.34 and 0.44. LLPS was not observed in SOA particles derived from isoprene and toluene when the average $\mathrm{O}: \mathrm{C}$ was between 0.52 and 1.30. Figure 6 and Table S1 in the Supplement show LLPS as a function of the average $\mathrm{O}: \mathrm{C}$ of SOA particles from previous studies (Lambe et al., 2015; Li et al., 2015; Renbaum-Wolff et al., 2016; Song et al., 2017). Also presented in Table S2 are the O: C values and experimental conditions for the SOA particles produced from $\alpha$-pinene ozonolysis and photooxidation investigated in this study and previous studies. In this study, data on the average $\mathrm{O}: \mathrm{C}$ values were not available; thus, we chose $\mathrm{O}: \mathrm{C}$ values from the literature that were closest to the experimental conditions (Table S2). The O : C values for the SOA particles derived from $\alpha$-pinene ozonolysis range from 0.42 to 0.44 as per Li et al. (2015), whereas those for SOA particles derived from $\alpha$-pinene photooxidation are between 0.40 and 0.90 according to Lambe et al. (2015).
According to the dataset of average $\mathrm{O}: \mathrm{C}$ values of different types of SOA particles from this study as well as previous studies, Fig. 6 shows that LLPS occurred when the average $\mathrm{O}: \mathrm{C}$ was between 0.34 and 0.44 . This range of the $\mathrm{O}: \mathrm{C}$ required for the occurrence of LLPS in the SOA particles is consistent with those from previous studies (Renbaum-Wolff et al., 2016; Rastak et al., 2017; Song et al., 2017). However, LLPS did not occur when the average $\mathrm{O}: \mathrm{C}$ was between 0.45 and 1.30 in this study. Using a new type of SOA particle generated from $\alpha$-pinene photooxidation, we showed that the absence of LLPS occurs over a wider range of $\mathrm{O}: \mathrm{C}$ values than reported by a previous work $(0.52-1.30$; Song et al., 2017).

Similar to the results for LLPS in the SOA particles with respect to the $\mathrm{O}: \mathrm{C}$, bulk solutions containing two organics and water also showed the miscibility gap (Ganbavale et al., 2015). For example, bulk solutions of two organics with a low $\mathrm{O}: \mathrm{C}$ and water (e.g., a mixture of 1-butanol, 1-propanol and water) formed two liquid phases (Ganbavale et al., 2015). However, bulk solutions of two organics with a high $\mathrm{O}: \mathrm{C}$ 


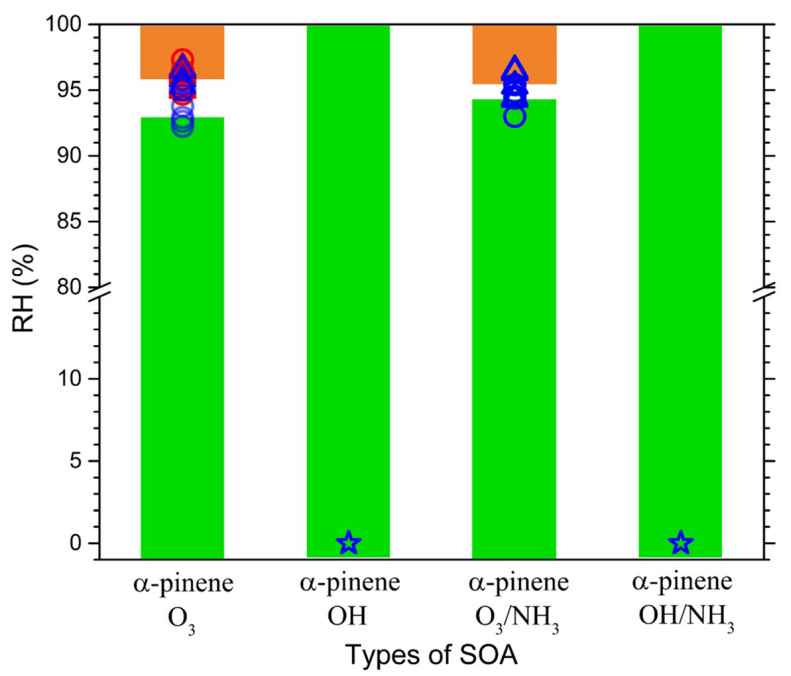

Figure 5. Relative humidity $(\mathrm{RH})$ at which the two phases were observed during RH scanning as a function of the four different types of SOA particles. Blue and red symbols are from this study and from Renbaum-Wolff et al. (2016), respectively. Circles represent the merging RH (MRH) for RH decreasing, and triangles represent the separation $\mathrm{RH}$ (SRH) for RH increasing. A RH of $0 \%$ indicates no LLPS. The green shaded region indicates one phase present, and the orange shaded region indicates two phases present in the SOA particles.

and water (e.g., a mixture of ethanol, acetic acid and water) formed a single liquid phase.

Previous studies have found nitrogen-containing SOA species in the presence of $\mathrm{NH}_{3}$ (Laskin et al., 2015; Y. Liu et al., 2015). These studies suggested that ammonium carboxylates were formed by neutralization between carboxylic acid and ammonia, and that amines were formed by carbonyl and ammonia via a Schiff base reaction ( $\mathrm{Na}$ et al., 2006, 2007; Laskin et al., 2015). The nitrogen to carbon ( $\mathrm{N}: \mathrm{C})$ ratio was reported to be $0.01-0.08$ based on aerosol mass spectrometry (AMS) and Fourier transform ion cyclotron resonance (FTICR MS) (Laskin et al., 2014; Y. Liu et al., 2015). It is noteworthy that ammonium carboxylates and amines are highly water soluble compounds. However, more accurate data regarding $\mathrm{O}: \mathrm{C}$ values of $\mathrm{SOA}$ particles in the presence of $\mathrm{NH}_{3}$ are needed.

Figure 6 also showed the range of the two liquid phases. The two phases consisting of an organic-rich shell and waterrich core were observed at $\mathrm{RH}$ values as high as $\sim 100 \%$ in all cases. Recent studies by Rastak et al. (2017) and Liu et al. (2018) showed, using laboratory work and modeling results, that the presence of LLPS in organic particles at $\sim 100 \% \mathrm{RH}$ can lead to lower surface tension, and finally a lower kinetic barrier to $\mathrm{CCN}$ activation. Our result can also provide additional insight into attempting more accurate predictions of the CCN properties of organic particles (Petters et al., 2006; Hodas et al., 2016; Renbaum-Wolff et al., 2016; Ovadnevaite et al., 2017; Rastak et al., 2017; Liu et al., 2018).

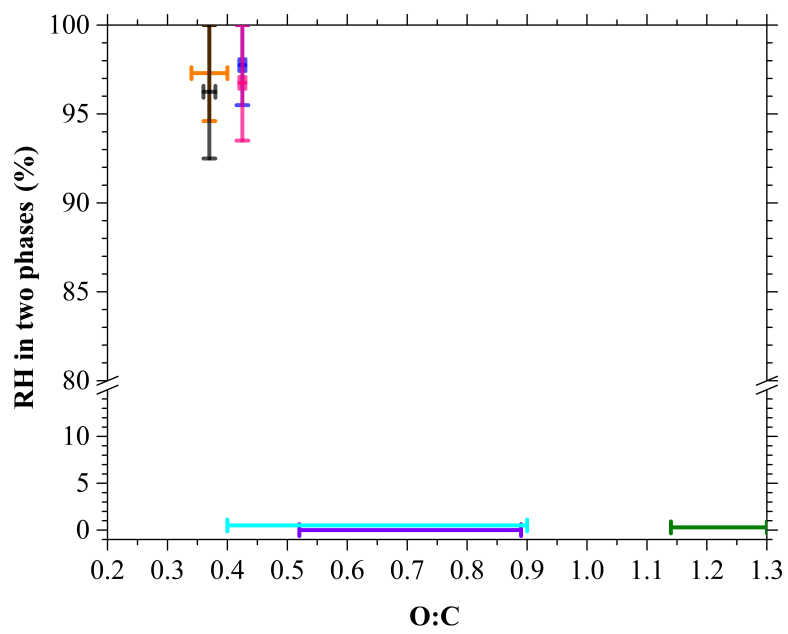

Figure 6. Relative humidity in two phases as a function of the average $\mathrm{O}: \mathrm{C}$ of SOA particles derived from $\alpha$-pinene ozonolysis (pink) and $\alpha$-pinene photooxidation (cyan) in this study, $\beta$-caryophyllene ozonolysis (black) from Song et al. (2017), $\alpha$-pinene ozonolysis (blue) from Renbaum-Wolff et al. (2016), limonene ozonolysis (orange) from Song et al. (2017), toluene photooxidation (green) from Song et al. (2017) and isoprene photooxidation (purple) from Rastak et al. (2017). The $\mathrm{O}: \mathrm{C}$ and related experimental conditions are summarized in Tables S1 and S2 in the Supplement.

\section{Summary}

In this study, we investigated liquid-liquid phase separation of SOA produced from both $\alpha$-pinene ozonolysis and $\alpha$ pinene photooxidation in the presence or absence of $\mathrm{NH}_{3}$. We conducted humidity cycles at a temperature of $289 \pm$ $0.2 \mathrm{~K}$ for four different SOA particles derived from $\alpha$-pinene ozonolysis, $\alpha$-pinene photooxidation, $\alpha$-pinene ozonolysis with $\mathrm{NH}_{3}$ and $\alpha$-pinene photooxidation with $\mathrm{NH}_{3}$, for particle mass concentrations of $\sim 500-1000 \mu \mathrm{g} \mathrm{m}^{-3}$. Among the four different types of SOA particles, LLPS occurred in SOA particles produced from $\alpha$-pinene ozonolysis at $95.8 \pm$ $2.3 \% \mathrm{RH}$ with increasing $\mathrm{RH}$ and in those produced from $\alpha$-pinene ozonolysis with $\mathrm{NH}_{3}$ at $95.4 \pm 2.9 \% \mathrm{RH}$ with increasing RH. In both types of particles, the two liquid phases coexisted up to $\sim 100 \%$ RH. However, LLPS was not observed in SOA particles produced from $\alpha$-pinene photooxidation and $\alpha$-pinene photooxidation with $\mathrm{NH}_{3}$. LLPS occurred in the SOA particles produced by $\alpha$-pinene ozonolysis, whereas no LLPS was observed in the SOA particles produced by $\alpha$-pinene photooxidation. In addition, the occurrence of LLPS did not depend on the presence or absence of $\mathrm{NH}_{3}$. Analysis of the dataset of the average $\mathrm{O}: \mathrm{C}$ values of different types of SOA particles from this study and those from previous studies indicated that LLPS occurred when the $\mathrm{O}: \mathrm{C}$ was less than $\sim 0.44$, and LLPS did not occur when the $\mathrm{O}: \mathrm{C}$ was greater than $\sim 0.40$.

Considering the range of the $\mathrm{O}: \mathrm{C}$ values of organic particles in the atmosphere $(0.2-1.0)$, these results provide addi- 
tional evidence that LLPS can occur in organic particles even without the presence of inorganic salts in the atmosphere. Moreover, LLPS occurred in the SOA particles at high RH values (as high as $\sim 100 \%$ ), implying that these results can provide additional information regarding the $\mathrm{CCN}$ properties of organic particles. Additional studies are needed to confirm LLPS in SOA particles produced using more atmospherically relevant VOC mass concentrations, particle mass concentrations and submicron sizes.

Data availability. Underlying material and related items for this paper are located in the Supplement.

Supplement. The supplement related to this article is available online at: https://doi.org/10.5194/acp-19-9321-2019-supplement.

Author contributions. MS and HJL conceived and designed the experiments. SH, JBL and ZBB performed the experiments and analyzed the data. SH and MS wrote the paper, and JBL and HJL edited the paper.

Competing interests. The authors declare that they have no conflict of interest.

Acknowledgements. This work was supported by the National Research Foundation of Korea grant funded by the Korea Government (MSIP; grant no. 2016R1C1B1009243). This research was supported by the National Strategic Project-Fine Particle of the National Research Foundation of Korea (NRF) funded by the Ministry of Science and ICT (MSIT), the Ministry of Environment (ME), and the Ministry of Health and Welfare (MOHW; grant no. 2017M3D8A1092015).

Financial support. This research has been supported by the National Research Foundation of Korea grant funded by the Korea Government (MSIP; grant no. 2016R1C1B1009243) and the National Strategic Project-Fine Particle of the National Research Foundation of Korea (NRF) funded by the Ministry of Science and ICT (MSIT), the Ministry of Environment (ME), and the Ministry of Health and Welfare (MOHW; grant no. 2017M3D8A1092015).

Review statement. This paper was edited by Jason Surratt and reviewed by three anonymous referees.

\section{References}

Altaf, M. B., Dutcher, D. D., Raymond, T. M., and Freedman, M. A.: Effect of particle morphology on cloud condensation nuclei activity, ACS Earth. Space. Chem., 2, 634-639, https://doi.org/10.1021/acsearthspacechem.7b00146, 2018.

Atkinson, R. and Aschmann, S. M.: Rate constants for the gasphase reactions of the $\mathrm{OH}$ radical with a series of aromatic hydrocarbons at $296 \pm 2 \mathrm{~K}$, Int. J. Chem. Kinet., 21, 355-365, https://doi.org/10.1002/kin.550210506, 1989.

Ault, A. P., Guasco, T. L., Ryder, O. S., Baltrusaitis, J., CuadraRodriguez, L. A., Collins, D. B., Ruppel, M. J., Prather, K. A., Bertram, T. H., and Grassia, V. H.: Inside versus Outside: Ion Redistribution in $\mathrm{HNO}_{3}$ Reacted Sea Spray Aerosol Particles as Determined by Single Particle Analysis, J. Am. Chem. Soc., 135, 14528-14531, 2013.

Babar, Z. B., Park, J.-H., and Lim, H.-J.: Influence of $\mathrm{NH}_{3}$ on secondary organic aerosols from the ozonolysis and photooxidation of $\alpha$-pinene in a flow reactor, Atmos. Environ., 164, 71-84, https://doi.org/10.1016/j.atmosenv.2017.05.034, 2017.

Baltensperger, U., Dommen, J., Alfarra, R., Duplissy, J., Gaeggeler, K., Metzger, A., Facchini, M. C., Decesari, S., Finessi, E., Reinnig, C., Schott, M., Warnke, J., Hoffmann, T., Klatzer, B., Puxbaum, H., Geiser, M., Savi, M., Lang, D., Kalberer, M., and Geiser, T.: Combined determination of the chemical composition and of health effects of secondary organic aerosols: The POLYSOA project, J. Aerosol Med. Pulm. D., 21, 145-154, https://doi.org/10.1089/jamp.2007.0655, 2008.

Bertram, A. K., Martin, S. T., Hanna, S. J., Smith, M. L., Bodsworth, A., Chen, Q., Kuwata, M., Liu, A., You, Y., and Zorn, S. R.: Predicting the relative humidities of liquid-liquid phase separation, efflorescence, and deliquescence of mixed particles of ammonium sulfate, organic material, and water using the organic-to-sulfate mass ratio of the particle and the oxygen-tocarbon elemental ratio of the organic component, Atmos. Chem. Phys., 11, 10995-11006, https://doi.org/10.5194/acp-11-109952011, 2011.

Ciobanu, V. G., Marcolli, C., Krieger, U. K., Weers, U., and Peter, T.: Liquid-liquid phase separation in mixed organic/inorganic aerosol particles, J. Phys. Chem. A., 113, 10966-10978, https://doi.org/10.1021/jp905054d, 2009.

Fard, M. M., Krieger, U. K., and Peter, T.: Shortwave radiative impact of liquid-liquid phase separation in brown carbon aerosols, Atmos. Chem. Phys., 18, 13511-13530, https://doi.org/10.5194/acp-18-13511-2018, 2018.

Forster, P., Ramaswamy, V., Artaxo, P., Berntsen, T., Betts, R., Fahey, D. W., Haywood, J., Lean, J., Lowe, D. C., Myhre, G., Nganga, J., Prinn, R., Raga, G., Schulz, M., and Van Dorland, R.: Changes in Atmospheric Constituents and in Radiative Forcing, in: Climate Change 2007: The Physical Science Basis. Contribution of working Group I to the Fourth Assessment Report of the Intergovernmental Panel on Climate Changes, edited by: Solomon, S., Qin, D., Manning, M., Chen, Z., Marquis, M., Averyt, K. B., Tignor, M., and Miller, H. L., Cambridge University Press, Cambridge, 2007.

Ganbavale, G., Zuend, A., Marcolli, C., and Peter, T.: Improved AIOMFAC model parameterisation of the temperature dependence of activity coefficients for aqueous organic mixtures, Atmos. Chem. Phys., 15, 447-493, https://doi.org/10.5194/acp-15447-2015, 2015. 
Hallquist, M., Wenger, J. C., Baltensperger, U., Rudich, Y., Simpson, D., Claeys, M., Dommen, J., Donahue, N. M., George, C., Goldstein, A. H., Hamilton, J. F., Herrmann, H., Hoffmann, T., Iinuma, Y., Jang, M., Jenkin, M. E., Jimenez, J. L., Kiendler-Scharr, A., Maenhaut, W., McFiggans, G., Mentel, Th. F., Monod, A., Prévôt, A. S. H., Seinfeld, J. H., Surratt, J. D., Szmigielski, R., and Wildt, J.: The formation, properties and impact of secondary organic aerosol: current and emerging issues, Atmos. Chem. Phys., 9, 5155-5236, https://doi.org/10.5194/acp9-5155-2009, 2009.

Heald, C. L., Collett Jr., J. L., Lee, T., Benedict, K. B., Schwandner, F. M., Li, Y., Clarisse, L., Hurtmans, D. R., Van Damme, M., Clerbaux, C., Coheur, P.-F., Philip, S., Martin, R. V., and Pye, H. O. T.: Atmospheric ammonia and particulate inorganic nitrogen over the United States, Atmos. Chem. Phys., 12, 10295-10312, https://doi.org/10.5194/acp-12-10295-2012, 2012.

Hodas, N., Zuend, A., Schilling, K., Berkemeier, T., Shiraiwa, M., Flagan, R. C., and Seinfeld, J. H.: Discontinuities in hygroscopic growth below and above water saturation for laboratory surrogates of oligomers in organic atmospheric aerosols, Atmos. Chem. Phys., 16, 12767-12792, https://doi.org/10.5194/acp-1612767-2016, 2016.

IPCC: Climate Change 2013: The Physical Science Basis. Contribution of Working Group I to the Fifth Assessment Report of the Intergovernmental Panel on Climate Change, edited by: Stocker, T. F., Qin, D., Plattner, G.-K., Tignor, M., Allen, S. K., Boschung, J., Nauels, A., Xia, Y., Bex, V., and Midgley, P. M., Cambridge University Press, Cambridge, UK and NewYork, NY, USA, 1535, 2013.

Jang, Y., Kim, G., and Chiriboga, D. A.: Correlates of sense of control among older Korean-American immigrants: Financial status, physical health constraints, and environmental challenges, Int. J. Aging Hum. Dev., 63, 173-186, https://doi.org/10.2190/9qmqTg4a-1ldc-Cnrr, 2006.

Jimenez, J. L., Canagaratna, M. R., Donahue, N. M., Prevot, A. S. H., Zhang, Q., Kroll, J. H., DeCarlo, P. F., Allan, J. D., Coe, H., Ng, N. L., Aiken, A. C., Docherty, K. S., Ulbrich, I. M., Grieshop, A. P., Robinson, A. L., Duplissy, J., Smith, J. D., Wilson, K. R., Lanz, V. A., Hueglin, C., Sun, Y. L., Tian, J., Laaksonen, A., Raatikainen, T., Rautiainen, J., Vaattovaara, P., Ehn, M., Kulmala, M., Tomlinson, J. M., Collins, D. R., Cubison, M. J., Dunlea, E. J., Huffman, J. A., Onasch, T. B., Alfarra, M. R., Williams, P. I., Bower, K., Kondo, Y., Schneider, J., Drewnick, F., Borrmann, S., Weimer, S., Demerjian, K., Salcedo, D., Cottrell, L., Griffin, R., Takami, A., Miyoshi, T., Hatakeyama, S., Shimono, A., Sun, J. Y., Zhang, Y. M., Dzepina, K., Kimmel, J. R., Sueper, D., Jayne, J. T., Herndon, S. C., Trimborn, A. M., Williams, L. R., Wood, E. C., Middlebrook, A. M., Kolb, C. E., Baltensperger, U., and Worsnop, D. R.: Evolution of Organic Aerosols in the Atmosphere, Science, 326, 1525-1529, 2009.

Kanakidou, M., Seinfeld, J. H., Pandis, S. N., Barnes, I., Dentener, F. J., Facchini, M. C., Van Dingenen, R., Ervens, B., Nenes, A., Nielsen, C. J., Swietlicki, E., Putaud, J. P., Balkanski, Y., Fuzzi, S., Horth, J., Moortgat, G. K., Winterhalter, R., Myhre, C. E. L., Tsigaridis, K., Vignati, E., Stephanou, E. G., and Wilson, J.: Organic aerosol and global climate modelling: a review, Atmos. Chem. Phys., 5, 1053-1123, https://doi.org/10.5194/acp-5-10532005, 2005.
Knopf, D. A., Alpert, P. A., and Wang, B. B.: The Role of Organic Aerosol in Atmospheric Ice Nucleation: A Review, ACS Earth. Space. Chem., 2, 168-202, https://doi.org/10.1021/acsearthspacechem.7b00120, 2018.

Krieger, U. K., Marcolli, C., and Reid, J. P.: Exploring the complexity of aerosol particle properties and processes using single particle techniques, Chem. Soc. Rev., 41, 6631-6662, https://doi.org/10.1039/c2cs35082c, 2012.

Kuwata, M. and Martin, S. T.: Phase of atmospheric secondary organic material affects its reactivity, P. Natl. Acad. Sci. USA, 109, 17354-17359, https://doi.org/10.1073/pnas.1209071109, 2012.

Lambe, A. T., Chhabra, P. S., Onasch, T. B., Brune, W. H., Hunter, J. F., Kroll, J. H., Cummings, M. J., Brogan, J. F., Parmar, Y., Worsnop, D. R., Kolb, C. E., and Davidovits, P.: Effect of oxidant concentration, exposure time, and seed particles on secondary organic aerosol chemical composition and yield, Atmos. Chem. Phys., 15, 3063-3075, https://doi.org/10.5194/acp15-3063-2015, 2015.

Laskin, A., Laskin, J., and Nizkorodov, S. A.: Chemistry of Atmospheric Brown Carbon, Chem. Rev., 115, 4335-4382, https://doi.org/10.1021/cr5006167, 2015.

Laskin, J., Laskin, A., Nizkorodov, S. A., Roach, P., Eckert, P., Gilles, M. K., Wang, B. B., Lee, H. J., and Hu, Q. C.: Molecular Selectivity of Brown Carbon Chromophores, Environ. Sci. Technol., 48, 12047-12055, https://doi.org/10.1021/es503432r, 2014.

Li, Y. J., Liu, P., Gong, Z., Wang, Y., Bateman, A. P., Bergoend, C., Bertram, A. K., and Martin, S. T.: Chemical Reactivity and Liquid/Nonliquid States of Secondary Organic Material, Environ. Sci. Technol., 49, 13264-13274, https://doi.org/10.1021/acs.est.5b03392, 2015.

Liu, P. F., Song, M., Zhao, T. N., Gunthe, S. S., Ham, S. H., He, Y. P., Qin, Y. M., Gong, Z. H., Amorim, J. C., Bertram, A. K., and Martin, S. T.: Resolving the mechanisms of hygroscopic growth and cloud condensation nuclei activity for organic particulate matter, Nat. Commun., 9, 4076, https://doi.org/10.1038/s41467-01806622-2, 2018.

Liu, T. Y., Wang, X. M., Deng, W., Zhang, Y. L., Chu, B. W., Ding, X., Hu, Q. H., He, H., and Hao, J. M.: Role of ammonia in forming secondary aerosols from gasoline vehicle exhaust, Sci. China. Chem., 58, 1377-1384, https://doi.org/10.1007/s11426015-5414-x, 2015.

Liu, Y., Liggio, J., Staebler, R., and Li, S.-M.: Reactive uptake of ammonia to secondary organic aerosols: kinetics of organonitrogen formation, Atmos. Chem. Phys., 15, 1356913584, https://doi.org/10.5194/acp-15-13569-2015, 2015.

Marcolli, C. and Krieger, U. K.: Phase changes during hygroscopic cycles of mixed organic/inorganic model systems of tropospheric aerosols, J. Phys. Chem. A., 110, 1881-1893, https://doi.org/10.1021/jp0556759, 2006.

Murray, B. J., Wilson, T. W., Dobbie, S., Cui, Z. Q., Al-Jumur, S. M. R. K., Mohler, O., Schnaiter, M., Wagner, R., Benz, S., Niemand, M., Saathoff, H., Ebert, V., Wagner, S., and Karcher, B.: Heterogeneous nucleation of ice particles on glassy aerosols under cirrus conditions, Nat. Geosci., 3, 233-237, https://doi.org/10.1038/Ngeo817, 2010.

Na, K., Song, C., and Cocker, D. R.: Formation of secondary organic aerosol from the reaction of styrene with ozone in the presence and absence of ammonia and water, Atmos. Environ., 
40, 1889-1900, https://doi.org/10.1016/j.atmosenv.2005.10.063, 2006.

Na, K., Song, C., Switzer, C., and Cocker, D. R.: Effect of ammonia on secondary organic aerosol formation from alpha-Pinene ozonolysis in dry and humid conditions, Environ. Sci. Technol., 41, 6096-6102, https://doi.org/10.1021/es061956y, 2007.

O'Brien, R. E., Wang, B. B., Kelly, S. T., Lundt, N., You, Y., Bertram, A. K., Leone, S. R., Laskin, A., and Gilles, M. K.: Liquid-Liquid Phase Separation in Aerosol Particles: Imaging at the Nanometer Scale, Environ. Sci. Technol., 49, 4995-5002, https://doi.org/10.1021/acs.est.5b00062, 2015.

Ovadnevaite, J., Zuend, A., Laaksonen, A., Sanchez, K. J., Roberts, G., Ceburnis, D., Decesari, S., Rinaldi, M., Hodas, N., Facchini, M. C., Seinfeld, J. H., and Dowd, C. O.: Surface tension prevails over solute effect in organic-influenced cloud droplet activation, Nature, 546, 637-641, https://doi.org/10.1038/nature22806, 2017.

Pankow, J. F.: Gas/particle partitioning of neutral and ionizing compounds to single and multi-phase aerosol particles. 1. Unified modeling framework, Atmos. Environ., 37, 3323-3333, https://doi.org/10.1016/S1352-2310(03)00346-7, 2003.

Pant, A., Parsons, M. T., and Bertram, A. K.: Crystallization of aqueous ammonium sulfate particles internally mixed with soot and kaolinite: Crystallization relative humidities and nucleation rates, J. Phys. Chem. A., 110, 8701-8709, https://doi.org/10.1021/jp060985s, 2006.

Parsons, M. T., Mak, J., Lipetz, S. R., and Bertram, A. K.: Deliquescence of malonic, succinic, glutaric, and adipic acid particles, J. Geophys. Res.-Atmos., 109, D06212, https://doi.org/10.1029/2003jd004075, 2004.

Petters, M. D., Kreidenweis, S. M., Snider, J. R., Koehler, K. A., Wang, Q., Prenni, A. J., and Demott, P. J.: Cloud droplet activation of polymerized organic aerosol, Tellus B, 58, 196-205, https://doi.org/10.1111/j.1600-0889.2006.00181.x, 2006.

Pöschl, U. and Shiraiwa, M.: Multiphase Chemistry at the Atmosphere-Biosphere Interface Influencing Climate and Public Health in the Anthropocene, Chem. Rev., 115, 4440-4475, https://doi.org/10.1021/cr500487s, 2015.

Rastak, N., Pajunoja, A., Navarro, J. C. A., Ma, J., Song, M., Partridge, D. G., Kirkevag, A., Leong, Y., Hu, W. W., Taylor, N. F., Lambe, A., Cerully, K., Bougiatioti, A., Liu, P., Krejci, R., Petaja, T., Percival, C., Davidovits, P., Worsnop, D. R., Ekman, A. M. L., Nenes, A., Martin, S., Jimenez, J. L., Collins, D. R., Topping, D. O., Bertram, A. K., Zuend, A., Virtanen, A., and Riipinen, I.: Microphysical explanation of the RH-dependent water affinity of biogenic organic aerosol and its importance for climate, Geophys. Res. Lett., 44, 5167-5177, 2017.

Reche, C., Viana, M., Karanasiou, A., Cusack, M., Alastuey, A., Artinano, B., Revuelta, M. A., Lopez-Mahia, P., BlancoHeras, G., Rodriguez, S., de la Campa, A. M. S., FernandezCamacho, R., Gonzalez-Castanedo, Y., Mantilla, E., Tang, Y. S., and Querol, X.: Urban $\mathrm{NH}_{3}$ levels and sources in six major Spanish cities, Chemosphere, 119, 769-777, https://doi.org/10.1016/j.chemosphere.2014.07.097, 2015.

Reis, S., Pinder, R. W., Zhang, M., Lijie, G., and Sutton, M. A.: Reactive nitrogen in atmospheric emission inventories, Atmos. Chem. Phys., 9, 7657-7677, https://doi.org/10.5194/acp-9-76572009, 2009.
Renbaum-Wolff, L., Song, M., Marcolli, C., Zhang, Y., Liu, P. F., Grayson, J. W., Geiger, F. M., Martin, S. T., and Bertram, A. K.: Observations and implications of liquid-liquid phase separation at high relative humidities in secondary organic material produced by $\alpha$-pinene ozonolysis without inorganic salts, Atmos. Chem. Phys., 16, 7969-7979, https://doi.org/10.5194/acp16-7969-2016, 2016.

Sharma, S. K., Rohtash, Mandal, T. K., Deb, N. C., and Pal, S.: Measurement of Ambient $\mathrm{NH}_{3}, \mathrm{NO}$ and $\mathrm{NO}_{2}$ at an Urban Area of Kolkata, India, Mapan-J. Metrol. Soc. I, 31, 75-80, https://doi.org/10.1007/s12647-015-0147-z, 2016.

Shiraiwa, M., Zuend, A., Bertram, A. K., and Seinfeld, J. H.: Gasparticle partitioning of atmospheric aerosols: interplay of physical state, non-ideal mixing and morphology, Phys. Chem. Chem. Phys., 15, 11441-11453, https://doi.org/10.1039/c3cp51595h, 2013.

Shiraiwa, M., Ueda, K., Pozzer, A., Lammel, G., Kampf, C. J., Fushimi, A., Enami, S., Arangio, A. M., Frohlich-Nowoisky, J., Fujitani, Y., Furuyama, A., Lakey, P. S. J., Lelieveld, J., Lucas, K., Morino, Y., Pöschl, U., Takaharna, S., Takami, A., Tong, H. J., Weber, B., Yoshino, A., and Sato, K.: Aerosol Health Effects from Molecular to Global Scales, Environ. Sci. Technol., 51, 13545-13567, https://doi.org/10.1021/acs.est.7b04417, 2017.

Song, M., Marcolli, C., Krieger, U. K., Zuend, A., and Peter, T.: Liquid-liquid phase separation in aerosol particles: Dependence on $\mathrm{O}: \mathrm{C}$, organic functionalities, and compositional complexity, Geophys. Res. Lett., 39, 1-5, https://doi.org/10.1029/2012GL052807, 2012a.

Song, M., Marcolli, C., Krieger, U. K., Zuend, A., and Peter, T.: Liquid-liquid phase separation and morphology of internally mixed dicarboxylic acids/ammonium sulfate/water particles, Atmos. Chem. Phys., 12, 2691-2712, https://doi.org/10.5194/acp12-2691-2012, 2012b.

Song, M., Marcolli, C., Krieger, U. K., Lienhard, D. M., and Peter, T.: Morphologies of mixed organic/inorganic/aqueous aerosol droplets, Faraday. Discuss., 165, 289-316, https://doi.org/10.1039/c3fd00049d, 2013.

Song, M., Liu, P., Martin, S. T., and Bertram, A. K.: Liquid-liquid phase separation in particles containing secondary organic material free of inorganic salts, Atmos. Chem. Phys., 17, 1126111271, https://doi.org/10.5194/acp-17-11261-2017, 2017.

Song, M., Ham, S., Andrews, R. J., You, Y., and Bertram, A. K.: Liquid-liquid phase separation in organic particles containing one and two organic species: importance of the average O:C, Atmos. Chem. Phys., 18, 12075-12084, https://doi.org/10.5194/acp-18-12075-2018, 2018.

Veghte, D. P., Altaf, M. B., and Freedman, M. A.: Size Dependence of the Structure of Organic Aerosol, J. Am. Chem. Soc., 135, 16046-16049, https://doi.org/10.1021/ja408903g, 2013.

Wang, B. B., Lambe, A. T., Massoli, P., Onasch, T. B., Davidovits, P., Worsnop, D. R., and Knopf, D. A.: The deposition ice nucleation and immersion freezing potential of amorphous secondary organic aerosol: Pathways for ice and mixedphase cloud formation, J. Geophys. Res.-Atmos., 117, D16209, https://doi.org/10.1029/2012jd018063, 2012.

Warner, J. X., Wei, Z., Strow, L. L., Dickerson, R. R., and Nowak, J. B.: The global tropospheric ammonia distribution as seen in the 13-year AIRS measurement record, Atmos. Chem. Phys., 16, 5467-5479, https://doi.org/10.5194/acp-16-5467-2016, 2016. 
Winston, P. W. and Bates, D. H.: Saturated Solutions for the Control of Humidity in Biological-Research, Ecology, 41, 232-237, https://doi.org/10.2307/1931961, 1960.

You, Y., Renbaum-Wolff, L., and Bertram, A. K.: Liquid-liquid phase separation in particles containing organics mixed with ammonium sulfate, ammonium bisulfate, ammonium nitrate or sodium chloride, Atmos. Chem. Phys., 13, 11723-11734, https://doi.org/10.5194/acp-13-11723-2013, 2013.

You, Y., Smith, M. L., Song, M., Martin, S. T., and Bertram, A. K.: Liquid-liquid phase separation in atmospherically relevant particles consisting of organic species and inorganic salts, Int. Rev. Phys. Chem., 33, 43-77, https://doi.org/10.1080/0144235X.2014.890786, 2014.

Zhang, Q., Jimenez, J. L., Canagaratna, M. R., Allan, J. D., Coe, H., Ulbrich, I., Alfarra, M. R., Takami, A., Middlebrook, A. M., Sun, Y. L., Dzepina, K., Dunlea, E., Docherty, K., DeCarlo, P. F., Salcedo, D., Onasch, T., Jayne, J. T., Miyoshi, T., Shimono, A., Hatakeyama, S., Takegawa, N., Kondo, Y., Schneider, J., Drewnick, F., Borrmann, S., Weimer, S., Demerjian, K., Williams, P., Bower, K., Bahreini, R., Cottrell, L., Griffin, R. J., Rautiainen, J., Sun, J. Y., Zhang, Y. M., and Worsnop, D. R.: Ubiquity and dominance of oxygenated species in organic aerosols in anthropogenically-influenced Northern Hemisphere midlatitudes, Geophys. Res. Lett., 34, https://doi.org/10.1029/2007GL029979, 2007.
Zhang, R. Y., Suh, I., Zhao, J., Zhang, D., Fortner, E. C., Tie, X. X., Molina, L. T., and Molina, M. J.: Atmospheric new particle formation enhanced by organic acids, Science, 304, 1487-1490, https://doi.org/10.1126/science.1095139, 2004.

Zuend, A. and Seinfeld, J. H.: Modeling the gas-particle partitioning of secondary organic aerosol: the importance of liquidliquid phase separation, Atmos. Chem. Phys., 12, 3857-3882, https://doi.org/10.5194/acp-12-3857-2012, 2012.

Zuend, A., Marcolli, C., Peter, T., and Seinfeld, J. H.: Computation of liquid-liquid equilibria and phase stabilities: implications for RH-dependent gas/particle partitioning of organicinorganic aerosols, Atmos. Chem. Phys., 10, 7795-7820, https://doi.org/10.5194/acp-10-7795-2010, 2010.

Zheng, J., Ma, Y., Chen, M. D., Zhang, Q., Wang, L., Khalizov, A. F., Yao, L., Wang, Z., Wang, X., and Chen, L. X.: Measurement of atmospheric amines and ammonia using the high resolution time-of-flight chemical ionization mass spectrometry, Atmos. Environ., 102, 249-259, https://doi.org/10.1016/j.atmosenv.2014.12.002, 2015. 